FACTA UNIVERSITATIS

Series: Physical Education and Sport, Vol. 17, No 3, 2019, pp. 559 - 568

https://doi.org/10.22190/FUPES190413050A

Narrative review article

\title{
INFLUENCE OF PHYSICAL AND SPORTS ACTIVITY ON MENTAL HEALTH
}

\author{
UDC 796:371.3
}

\author{
Nataša Arsović ${ }^{1}$, Radmila Đurović ${ }^{2}$, Rada Rakočević ${ }^{2}$ \\ ${ }^{1}$ Elementary School Bora Stanković, Belgrade, Serbia \\ ${ }^{2}$ Faculty of Sport, Union Nikola Tesla University, Belgrade, Serbia
}

\begin{abstract}
The purpose of this narrative review is to investigate evidence for physical and sports activity affecting mental health. Knowledge about preemptive and treatment effects on achieving and maintaining an average level of physical abilities is considered nowadays to be a significant achievement of modern science. This knowledge has influenced the creation of various programs for the improvement of the holistic wealth of an individual. The accent is on the investigation of psychological benefits of exercising both in terms of prevention, and in treatment of stress, depression and anxiety. It is necessary to establish a parallel between the positive and negative influences of sports activity on mental health, and use of the individual approach in the way, attitude, motive, intensity and scope of recreational/sport activity. Regarding professional athletes, harmonization of physical and psychological preparation with adequate professional supervision is of great importance. Coordinated physical and psychological preparations can act positively on the attainment and achievement of goals, but also on the preservation and maintenance of mental health.
\end{abstract}

Key words: Mental Health, Physical Activity, Sports Activity, Well Being

\section{INTRODUCTION}

We are witnessing everyday life where people often talk about going to the gym, running, pilates, aerobics in order to somehow eliminate the stress accumulated during the day. More and more common sports activities are carried out in our work organizations and physical activity is popular with the working age group. All participants of such activities report that they feel better, happier and more satisfied after exercise. However, exercise, whether recreational or professional, may be viewed differently with respect to mental health. Positive and negative effects of sports activity on mental health should be analyzed

Received April 13, 2019/ Accepted December 24, 2019

Corresponding author: Nataša Arsović

Elementary School Bora Stanković, Paunova 19a, 11040 Belgrade, Serbia

Phone: + 381113983590 •E-mail: natasaarsovic@gmail.com 
in parallel, taking into account under what conditions sports activity is favorable and under which it is unfavorable to the individual. It could be argued that the daily physical activity of the appropriate content, intensity, duration and frequency undoubtedly contributes to the better mental health of the individual. The concept of mental health includes a subjective sense of well-being, self-efficacy, autonomy, the ability to establish harmonious relationships with other people, and the ability to realize one's own intellectual and emotional potentials, i.e., the ability to constructively change the social and physical environment (Jevtić, Popović, $\&$ Bibić, 2008). The most important influences on learning life skills that underlie mental health are having a healthy lifestyle.

The purpose of this narrative review is to investigate evidence for physical and sports activity affecting mental health.

\section{A THEORETICAL CONSIDERATION OF THE PROBlem}

\section{Psychological well-being of exercise}

Numerous studies (Wiese, Kuykendall, \& Tay, 2018; Zayed, Ahmed, Van Niekerk, \& Ho, 2018; Kostić, 2017; Pate, 1995; Lee, Hsieh, \& Paffenbarger, 1995) have confirmed the psychological well-being of exercise in both prevention and treatment of stress, depression and anxiety. "Exercise" is planned, structured, repetitive, and purposeful subcategory of physical activity with an objective of improvement or maintenance of one or more components of physical fitness. "Exercise" and "exercise training" generally relate to physical activity performed during leisure time and frequently are used interchangeably. Their primary aim is improving or maintaining physical fitness, physical performance, or health (Office of Disease Prevention and Health Promotion, 2008). The findings showed that physical activity in recommended amounts is an effective tool in the treatment of depression (Hallgren et al., 2016). The International Society of Sport Psychology (1992) points out that: 1. Exercise can be associated with reduced anxiety; 2 . Exercise can be associated with the relief of symptoms in mild to moderate depression; 3 . Long-term exercise is associated with a decrease in neuroticism and anxiety; 4 . Exercise can be positive in the treatment of severe depression; 5. Exercise can help reduce various stress indicators; 6 . Exercise can have an emotional effect in all seasons and in both sexes. Regular exercise and physical activity lowers the prevalence of chronic disease(s). According to Anderson \& Shivakumar (2013) there is strong evidence that $2-2.5 \mathrm{~h}$ of moderate- to high-intensity exercise per week is sufficient to reduce one's risk for the occurrence of chronic disease (-s). Exercise improves one's self-esteem, and sense of wellbeing. Observations by which individuals who exercise regularly exhibit slower rates of age-related memory and cognitive decline in comparison to those who experience more sedentary lifestyle provided the fundaments in using exercise to improve memory and cognition in cognitive disorders. Based on the results of Cooper's (Cooper, 1969) study, athletes are less anxious, less compulsive and emotionally stable, and more socially adaptable and confident than non-athletes. According to research results, Knapen, Vancampfort, Morien, \& Marchal (2015) indicate that the impact of physical activity on mild and moderate depression is the same as pharmacological therapy for depression and/or psychotherapy, while severe depression requires exercise therapy/ treatment. In clients with severe depression, it is necessary to work on the intrinsic motivation to exercise at the same time to make the treatment effects more lasting. Positive emotions 
occur through the exercise of moderate sporting activity in the context of recreation, training and competition. Positive emotions, generated by sports activity, suppress negative emotions and have antidepressant effects in relation to them (Maklecova, Filipović, Naumović, Ivetić, \& Mendzerickilj, 1999). Within the theoretical models, the relation between running and mood improvement is considered in the explanation of depression. According to the behavioral model, depression occurs as a consequence of a reduced amount of positive reinforcement in an individual's life, and lack of necessary social skills, and running can be understood as an activity that offers validation both for the individual and through changes in body appearance, and provides for additional social interactions. According to the cognitively behavioral model of depression, running effort temporarily interrupts selective thought processes, focused on the negative aspects of events, and focuses on sensations from one's body. The short-term goal that is set that day is achieved, the activity itself is a success and negative thoughts are transformed into positive ones, confidence is built up and, over time, it transfers to all aspects of life. It could be assumed that running is multidimensional, i.e., through all the described mechanisms, further checking of running as an integral treatment of depression would certainly be worthwhile (Popović \& Simonović, 2008). Summarizing the results of various studies, Lazarević (1994) points out that successful athletes have greater emotional stability, better emotional self-control and less anxiety, higher self-esteem and safety, greater degree of perseverance, greater ability to adapt in stress conditions and high motivation in stress conditions.

When it comes to children, the results of studies indicate that their physical activity is accompanied by a positive attitude about themselves, that participation in physical activity programs boosts their confidence and that physical exercise contributes to the formation of a positive attitude towards themselves and their body, which is important for emotional stability and in general for nurturing the mental health of the individual (Mladenović, 2005). However, coaches working with girls and boys need to make sure that the sporting experience of young contestants is positive. The youth sports program should emphasize the development of self-worth, self-confidence and independence. Victory and success in sports during this period should be sidelined (Cox, 2006). In this way, they would perform a good psychological preparation for sports, but also for life, stressful situations later. Better physical fitness achieved through training or exercise serves as protection against life stress (Brown, 1991). Life stress is the accumulation of tension caused by different life challenges. People who exercise regularly are less susceptible to the negative impact of life stress (Brown, 1991). In the literature, an individual's ability to protect themselves from life stress through regular exercise is called a "stress vaccine". Speaking of the positive impact of exercise, the literature also points to the positive contributions of exercise in individuals with anxiety or depression, since improvement in these individuals is possible. Although the impact of exercise to relieve anxiety is generally similar to that of depression, one clear distinction needs to be emphasized (Cox, 2005). While anaerobic exercise (high intensity, short duration) effectively relieves depression, so does anxiety. In relation to this, aerobic exercise more successfully affects overall mood than anaerobic exercise (Cox, 2005). Aerobic exercise has proven to be significant in the elderly, as such exercises selectively maintain some of the cognitive functions that normally decline. According to Bernstein \& McNally (2017) aerobic exercise relieves depressive signals by accumulating recurring mood enhancements. Hence, if a bout of exercise boosts affect, chronic exercise should foster a long-term mood elevation. In addition, exercise among the elderly has proven 
effective in preserving spatial relationships and some aspects of memory (Campbell \& Jones, 1994). Three reviews of studies related to anxiety, depression, and exercise have been published (North, McCullagh, \& Tran, 1990). The results of a meta-analysis that included 80 studies conducted from 1969 to 1989 that examined the impact of exercise on depression indicated that: 1 . Acute and regular exercise effectively relieves depression; 2 . The greatest reduction in depression was present in subjects undergoing psychological treatment; 3. Exercise is associated with alleviating the symptomatology of depression; 4. Exercise effectively relieves depression in mentally healthy people as well as in those involved in psychiatric treatment; 4. All types of exercise relieve depression; 5. The duration of the exercise program, as well as the amount of exercise, are related to the degree of depression; 6. Exercise combined with psychotherapy is more effective in relieving depression than exercise alone.

The results of Petruzzelo, Landers, Hatfield, Kubitz, \& Salazar (1991) that examined the effect of exercise on anxiety indicate: 1 . Exercise time must be greater than 20 minutes to relieve anxiety in an individual; 2. Progressive relaxation to the same extent as exercise has the effect of alleviating anxiety as a condition 3. Exercise is more effective than progressive relaxation in relieving anxiety as a trait; 4 . Anaerobic exercise does not affect anxiety relief; 5. Regular and acute aerobic exercise effectively relieves anxiety; 6 . The exercise program must last for more than 10 weeks in order to show anxiety relief. A review of well-controlled studies from 1985 to 1990 (LaFontaine et al., 1992) that examined the relationship between aerobic exercise and anxiety indicate that: 1 . There is an association between exercise and anxiety and depression; 2 . Aerobic exercise works more effectively in mild to moderately severe depression and anxiety; 3 . Reduced anxiety and depression with exercise can occur even when there is no improvement in fitness; 4 . The hypothesis about the role of exercise in alleviating depression and anxiety cannot be refuted.

On the other hand, most of the existing research examining depression in sport has focused on its prevalence in early adulthood (Proctor \& Boan-Lenzo, 2010). Research findings indicate that the prevalence of depression is lower in athletes than in non-athletes.

Despite the significance of physical activity in treatments for depression and anxiety, there are numerous factors that impede the promotion and exercise of physical activity within clinical practice. Glavocki, Weatherson, \& Faulner (2019), examining barriers and support for physical activity involvement in health services for clients with mental illness, indicate staff beliefs that clients cannot overcome obstacles to physical activation and lack of training on how to promote physical activity with these clients. To overcome the perceived barriers, the authors emphasize the importance of integration and promotion of physical activity in mental health care, which is likely to require broader systemic changes in the treatment itself.

\section{The negative side of exercise}

The purpose of the training is to raise general and specific abilities in a person who is engaged in some kind of sports activity. However, the concept of the training itself and the general condition of the body must be followed, because it is not easy to reach maximum potentials in sports and exercise. In sports and exercise, too much coaching and training leads to the experience of weariness, overtraining, and the appearance of burnout (Cox, 2005). According to Sliva (1990), the stress that results from coaching itself is a necessary 
product of psychophysiological stress, and its consequences can be positive and negative. Positive adaptation to such stress results in progress in training. On the contrary, negative adaptation to stress training leads to a lack of progress. Exhaustion is the inability to adapt to the stress that results from certain physical activity. If an athlete does not manage to overcome the weariness of training and adapts to the stress of training, overtraining occurs. It represents poor psychophysical functioning. One of the indicators of overtraining is mood disorder, and this indicator is considered to be the simplest early warning of lack of adaptation to stress training (Sliva, 1990). Mood disorders are common in swimmers and long-distance runners, and sometimes occur in basketball and other sports. If, despite the visible consequences, a negative adjustment to stress training continues, burnout occurs. Combustion is the third stage of training stress and represents a comprehensive psychophysiological response to repeated failed efforts to meet the demands of stress training. The psychological manifestations of burnout are: mood disorders, low self-esteem, behavioral changes in social interactions (cynicism, insensitivity), and a negative reaction to daily stress. When burnout occurs, withdrawal from a stressful environment is inevitable (Sliva, 1990). In professional sports, even when overtraining and burnout have not occurred due to the pressure and stress during training, depression may occur, so it is recommended that sports psychologists, coaches and parents be supported in recognizing and understanding these experiences. It is evident that many elite athletes can use sports at different times of life as a refuge from life's difficulties, including depression itself (Howells \& Fletcher, 2015). However, in this case, sport becomes a source of poor mental health, especially for athletes with a strong sports identity and those who have a great fear of failure. In addition, depression can also be a consequence of overtraining, so the self-loading and recovery of athletes must be controlled by professionals (coaches, sports psychologists). In a survey of German elite athletes (Nixdorf, Frank, Hautzinger, \& Beckmann, 2013), research findings indicate that depressive symptoms are more common in athletes who practice individually than in those who engage in team sports. Several studies (Yang et al., 2007; Storch, Storch, Killiany, \& Roberti, 2005) have proven that depression is more common in female athletes. Specifically, more depressive symptoms were observed in female athletes than in male athletes, both male and female non-athletes.

\section{Social anxiety over looks}

In the literature, social anxiety about appearance, addiction to exercise, and eating disorders are often described in a related way, which in some cases is justified and not in others (Corazza et al., 2019).

Social anxiety about appearance is the anxiety a person experiences when he or she thinks that other people are negatively evaluating their appearance (Cox, 2005). This type of anxiety is related to the concepts of body perception and self-assessment of body appearance. Body self-assessment is measured using a Physical Self-Perception Profile (PSPP) designed by the psychologists Fox \& Corbin (1989). PSPP evaluates how a person perceives their own physical attractiveness, physical fitness, physical strength and fitness. This is actually the basis for Fox's (hierarchical) model. According to this model, positive self-assessment of one's own appearance contributes to the development of self-esteem. People with positive self-esteem will love competitive situations and enjoy social exercise. On the contrary, people who have a negative self-image or have anxiety about their appearance will avoid competitive situations as well as exercise in society (Crawford \& Eklund, 1994). 


\section{Addiction to exercise}

Exercise addiction is considered a psychophysiological dependence on a regular exercise program (Oberle, Watkins, \& Burkot, 2018; Anshel, 1991). The person who developed this type of addiction is losing the benefits of regular moderate exercise. According to Weinstein, Maayan, \& Weinstein (2015) if exercise addiction is associated with high levels of anxiety and depression their exercise may not be efficient in reducing anxiety and depression as intended. Individuals that may need professional help in coping with anxiety and depression, could experience clinical implications (Weinstein, Maayan, \& Weinstein, 2015).

The term used in the literature to describe exercise addicts is the passionate runner. Passionate runners are highly motivated for physical activity, and when prevented from exercising they experience high psychological dissatisfaction and anxiety (Conboy, 1994). Anshel, 1991). They also show a greater degree of depression, anxiety, and discomfort if they deviate from their exercise schedule. From the standpoint of attribution theory, a healthy lifestyle does not include dependence on exercise, because in this case, the activity controls the person, so he often remains in the exercise itself despite the negative consequences such as evident pain and/or injury.

\section{Eating disorders}

In order to maintain a certain body weight and achieve certain results in sports, athletes make various mistakes in their diet concept. Eating disorders occur in all sports, but the incidence is different in some sports. As in the general population, eating disorders are more common in women than in men. The two most common eating disorders present in athletes are anorexia nervosa and bulimia nervosa (Cox, 2005). Anorexia nervosa and bulimia nervosa lead to semi-starvation and dehydration, which can lead to loss of muscle mass, decreased aerobic and anaerobic abilities, poor judgment and other complications that adversely affect the health of the athlete (Mladenović, 2008). Anorexia nervosa and bulimia nervosa are the most severe forms of eating disorders in athletes, but not the only ones. Other eating disorders include abuse of tablet pills, diuretics and laxatives (Cox, 2005).

The relatively new diagnosis of orthorexia in athletes and regular exercisers has been poorly examined. A key manifestation of orthorexia is the obsession with healthy and proper nutrition, characterized by restrictive diets while avoiding foods that a person considers unhealthy (Bozeglav, 2016).

\section{Explanations of the relationship between exercise and better mental health}

The correlation between exercise and better mental health is explained by the cognitive behavioral hypothesis, the social interaction hypothesis, the attentional hypothesis, the amine hypothesis, the cardiovascular readiness hypothesis, and the endorphin hypothesis.

\section{The cognitively behavioral hypothesis}

The basic premise of the cognitively behavioral hypothesis is to encourage positive thinking and feeling through exercise that is contrary to states of negative mood (North et al., 1990). This theoretical explanation is analogous to Bandura's (1977) theory of selfefficacy. According to Bandura's theory, an individual experiences increased selfefficacy after mastering a perceived difficult task. People who are not physically active 
consider exercise a difficult task. If such persons start exercising regularly, they will have an experience of achievement and self-efficacy. Doing so will prevent the negative emotions associated with depression and anxiety.

\section{Social interaction hypothesis}

The social interaction hypothesis indicates that exercise in society (with friends, colleagues) provides pleasure and improves mental health (Rosa et al., 2015; Cox, 2005). The literature states that the social interaction hypothesis partly explains the psychological benefits of exercise and is not fully acceptable, since numerous benefits of regular exercise have been proven whether for individual or group activities.

\section{Attention Deficit Hypothesis}

The basic premise of the attention-grabbing hypothesis is the ability to distract an individual from stress and frustration. Unlike other distracting fun activities, exercising regularly is a more powerful and effective way of relieving a negative mood (Choi, Han, Kang, Jung, \& Renshaw, 2015; Bahrke \& Morgan, 1978). However, the attention span may explain the short-term relief of depression and anxiety, but not the long term.

\section{The amine hypothesis}

The basic premise of the amine hypothesis is the association between increased neurotransmitter excretion and better mental health. Research results show that depressed individuals have lower levels of secretion of noradrenaline, serotonin, and dopamine (Pytka et al., 2016; North et al., 1990; Morgan, 1985), while exercise stimulates the production of neurotransmitters that have a positive effect on mood. According to Szabo, Griffiths, \& Demetrovics (2019) among other functions, catecholamines, are involved in the response to stress and sympathetic responses to exercise and their activity is altered by exercise. Because central catecholamine levels are involved in regulating mood and affect and play significant role in mental dysfunctions such as depression, the alteration of catecholamines by exercise may be an attractive explanation. However, it is unclear whether the peripheral changes in catecholamines have an effect on brain catecholamine levels or vice versa. Furthermore, the changes in brain catecholamine levels during exercise in humans are unknown, because direct measurement in the human brain is not possible.

\section{Cardiovascular readiness hypothesis}

The basic assumption of the cardiovascular readiness hypothesis is the correlation between cardiovascular fitness, i.e., aerobic endurance and better mood (Morgan, 1985). However, the cardiovascular readiness hypothesis does not find confirmation in the literature.

\section{The endorphin hypothesis}

The endorphin hypothesis indicates that general euphoria is caused by endorphin and alleviates levels of depression, anxiety, confusion and other negative moods. However, some studies did not support this hypothesis, since the results indicate a connection between certain level of endorphins in blood plasma and a positive mood (Kraemer, Dzewaltowski, Blair, Rinehardt, \& Castracane, 1990). 
According to Motta (2018) there are couple critiques of the endorphin hypothesis: 1) circulating endorphin levels are not reflective of brain endorphin levels and endorphins cannot cross the blood brain barrier. So even if circulating or peripheral endorphin levels increased, this should not have an impact on brain mediated emotional states; 2) when the endorphin blocking substance naloxone, an opiate antagonist, is provided to those experiencing the runners high, the elevation in mood is not diminished. If endorphins were causal to exercise induced mood changes, one would expect a significant deterioration in mood following a naloxone injection.

\section{CONCLUSION}

Although plausible explanations for the relationship between mental health and exercise, no hypothesis provides a complete and satisfactory explanation for the reasons for improving mental health through exercise. However, the lack of a definitive explanation should not diminish the importance of the relationship, as the optimal level of regular exercise and sports activity certainly deserves attention for the care of mental health and the treatment of mood disorders. Proper conception of exercise involves the ability of the trainer to understand the balance between the positive and negative impact of intense exercise. When it comes to professional athletes, we emphasize the importance of compliance of physical and psychological preparation with adequate professional supervision. Consistent physical and psychological preparations can have a positive effect on the achievement of goals, but also on the good preservation and maintenance of mental health. With some caution, we can point out that the positive outcome of gaining achievement (winning, stagnating or neutralizing certain disorders, better appearance, reducing excess weight), encourages positive emotions that have a positive effect on the personality.

Greater attention should be paid to the organization and quality of physical/sports activities. In addition, it is necessary to examine which sports/physical activity more or less affect mental health. The only thing that can be said with certainty is that the effects of different sports cannot and are not equal. We emphasize the importance of including exercise and the positive effects of regular moderate exercise in clinical patients with psychiatric disorders. An empirical study is being prepared by the author of the article on precisely this topic.

\section{REFERENCES}

Anderson, E. H., \& Shivakumar, G. (2013). Effects of exercise and physical activity on anxiety. Frontiers in Psychiatry, 4, 27.

Anshel, M.H. (1991). A psycho-behavioral analysis of addicted versus non-addicted male and female exercisers. Journal of Sport Behavior, 14(2), 145-154.

Bahrke, M.W., \& Morgan, W.P. (1978). Anxiety reduction following exercise and medication. Cognitive Therapy and Research, 2, 323-333.

Bandura, A. (1977). Self-efficacy: Toward a unifying theory of behavioral change. Psychological Review, 84, 191-215.

Bernstein, E.E., \& McNally, R.J. (2017). Acute aerobic exercise helps overcome emotion regulation deficits. Cognition and Emotion, 31(4), 834-843.

Bozeglav (2016). Prehreanske motnje in ortorekija v poveyavi s fitnesom (Nutritional disorders and orthorrhea in augmentation with fitness). Graduate paper. University of Ljubljana. In Slovenian 
Brown, J.D. (1991). Staying fit and staying well: Physical fitness as a moderator of life stress. Journal of Personality and Social Psychology, 60(4), 551-561.

Campbell, E., \& Jones, G. (1994). Psychological wellbeing in wheelchair sport participants and nonparticipants. Adapted Physical Activity Quarterly, 11, 404-415.

Choi, J.W., Han, D.H., Kang, K.D., Jung, H.Y., \& Renshaw, P.F. (2015). Aerobic exercise and attention deficit hyperactivity disorder: Brain research. Medicine and Science in Sports and Exercise, 47(1), 33.

Conboy, J. K. (1994). The effects of exercise withdrawal on mood states in runners. Journal of Sport Behavior, $17,188-203$.

Cooper, L. (1969). Athletics, activity, and personality: A review of the literature. Research Quarterly, 40, 17-22.

Corazza, O., Simonato, P., Demetrovics, Z., Mooney, R., van de Ven, K., Roman-Urrestarazu, A., et al. (2019). The emergence of Exercise Addiction, Body Dysmorphic Disorder, and other image-related psychopathological correlates in fitness settings: A cross sectional study. PloS one, 14(4), e0213060.

Cox, R. (2005). Psihologija sporta (Psychology of sport). Zagreb: Naklada Slap. In Croatian

Crawford, S., Eklund, R.C. (1994). Social physique anxiety, reasons for exercise, and attitudes toward exercise settings. Journal of Sport and Exercise Psychology, 16, 70-82.

Fox, K.R., \& Corbin, C.B. (1989).The physical self perception profile: Development and preliminary validation. Journal of Sport and Exercise Psychology, 11, 408-430.

Glowacki, K., Weatherson, K., \& Faulkner, G. (2019). Barriers and facilitators to health care providers' promotion of physical activity for individuals with mental illness: A scoping review. Mental Health and Physical Activity, 16, 152-168.

Hallgren, M., Herring, M. P., Owen, N., Dunstan, D., Ekblom, Ö., Helgadottir, B., et al. (2016). Exercise, physical activity, and sedentary behavior in the treatment of depression: Broadening the scientific perspectives and clinical opportunities. Frontiers in Psychiatry, 7, 36.

Howells, K., \& Fletcher, D. (2015). Sink or swim: Adversity- and growth related experiences in Olympic swimming champions. Psychology of Sport and Exercise, 16, 37-48.

International Society of Sport Psychology (1992). Physical activity and psyhological benefits: A position statement from the international society of sport psychology. Journal of Applied Sport Psychology, 4, 94-98.

Jevtić, M, Popović, M, Bibić, Ž (2008). Investing in mental health. Eskulap, 3(2), 114-121.

Knapen, J., Vancampfort, D, Morien, Y., Marchal, Y. (2015). Exercise therapy improves both mental and physical helth in patients with major depression. Disabilty and Rehabilitation, 37 (16), 1490-1495.

Kostić, M. (2017). Stress, adaptation and the possible effect of physical exercise. Facta Universitatis Series Physical Education and Sport, 15(2), 329-340.

Kraemer, R.R., Dzewaltowski, D.A., Blair, M.S., Rinehardt, K.F., \& Castracane, V.D. (1990). Mood alteration from treadmil running and its relationship to betaendorphine, corticotrophine, and growth hormone. The Journal of Sports Medicine and Physical Fitness, 30(3), 241-246.

Lazarević, Lj. (1994). Psihološka priprema sportista (Psychological preparation of athletes). Belgrade: Faculty of Physical Culture, University of Belgrade. In Serbian

LaFontaine, T.P., DiLorenzo, T.M., Frensch, P.A., Stucku-Ropp, R.C., Bargman, E.P., \& McDonald, D.G. (1992). Aerobic exercise and mood: A brief rewiev, 1985-1990. Sports Medicine, 13 (3), 160-170.

Lee, I.M., Hsieh, C.C., \& Paffenbarger, R.S. (1995). Exercise intensity and longevity in men: the Harvard Alumni Health Study. Jama, 273(15), 1179-1184.

Maklecova, M.G., Filipović, D., Naumović, D., Ivetić, V., \& Mendzerickilj, A.M. (1999). Emotivna stanja u toku sportskih aktivnosti - neurofiziološka osnova (Emotional states during sports activitiesNeurophysiological basis). Sport $i$ zdravlje, 3, 90-93. In Serbian

Mladenović, V. (2005). Psihologija u sportu (Psychology in Sport). Belgrade: Sports Academy. In Serbian

Morgan, W.P. (1985). Affective beneficence of vigorous physical activity. Medicine and Science in Sports and Exercise, 17, 94-100.

Motta, R. (2018). The role of exercise in reducing PTSD, and negative emotional states. In: Psychology of Health-Biopsychosocial Approach. Intech-Open.

Nixdorf, I., Frank, R., Hautzinger, M., \& Beckmann, J. (2013). Prevalence of depressive symptoms and correlating variables among German elite athletes. Journal of Clinical Sport Psychology, 7(4), 313-326.

North, T.C., McCullagh, P., \& Tran, Z.V. (1990). Effect of exercise on depression. In: K.B. Pandolf \& J.O. Holloszy (Eds.), Exercise and sport science reviews, (pp. 379-415). Baltimore: William \& Wilkins.

Oberle, C.D., Watkins, R.S., \& Burkot, A.J. (2018). Orthorexic eating behaviors related to exercise addiction and internal motivations in a sample of university students. Eating and Weight Disorders-Studies on Anorexia, Bulimia and Obesity, 23(1), 67-74. 
Office of Disease Prevention and Health Promotion. (2008). Department of Health and Human Services: 2008 physical activity guidelines for Americans. Washington DC: United States Department of Health and Human Services

Pate, R.R. (1995). Physical activity and public health. Journal of the American Medical Association, 273, $402-407$.

Popović, A., \& Simonovć,M. (2008). Psihologija (Psychology). Priština: Center for Multidisciplinary Research. In Serbian

Proctor, S. L., \& Boan-Lenzo, C. (2010). Prevalence of depressive symptoms in male intercollegiate studentathletes and non-athletes. Journal of Clinical Sport Psychology, 4(3), 204-220.

Pytka, K., Podkowa, K., Rapacz, A., Podkowa, A., Żmudzka, E., Olczyk, A., et al. (2016). The role of serotonergic, adrenergic and dopaminergic receptors in antidepressant-like effect. Pharmacological Reports, 68(2), 263-274.

Reche-García, C., De Francisco, C., Martinez-Rodriguez, A., \& Ros-Martínez, A. (2018). Relationship among sociodemographic and sport variables, exercise dependence, and burnout: a preliminary study in athletes. Anales de Psicologia, 34(2), 398-404.

Rosa, J.P., de Souza, A.A., de Lima, G.H., Rodrigues, D.F., de Aquino Lemos, V., da Silva Alves, E., et al. (2015). Motivational and evolutionary aspects of a physical exercise training program: a longitudinal study. Frontiers in Psychology, 6, 648.

Sliva, J. M. (1992). Psychological momentum and skill performance: A laboratory study. Journal of Applied Sport Psychology, 14,119-133.

Storch, E.A., Storch, J.B., Killiany, E.M., \& Roberti, J.W. (2005). Self-reported psychopathology in athletes: a comparison of intercollegiate student-athletes and non-athletes. Journal of Sport Behavior, 28(1), 86-98.

Szabo, A., Griffiths, M.D., \& Demetrovics, Z. (2019). Psychology and exercise. In: Nutrition and enhanced sports performance (pp. 65-73). Elsevier Inc.

Weinstein, A., Maayan, G., \& Weinstein, Y. (2015). A study on the relationship between compulsive exercise, depression and anxiety. Journal of Behavioral Addictions, 4(4), 315-318.

Wiese, C.W., Kuykendall, L., \& Tay, L. (2018). Get active? A meta-analysis of leisure-time physical activity and subjective well-being. The Journal of Positive Psychology, 13(1), 57-66.

Yang, J., Peek-Asa, C., Corlette, J., Cheng, G., Foster, D., \& Albright, J. (2007). Prevalence of and risk factors associated with symptoms of depression in competitive collegiate student athletes. Clinical Journal of Sports Medicine, 17 (6), 481-487.

Zayed, K.N., Ahmed, M.D., Van Niekerk, R.L., \& Ho, W.K.Y. (2018). The mediating role of exercise behaviour on satisfaction with life, mental well-being and BMI among university employees. Cogent Psychology, 5(1), 1430716.

\section{UTICAJ FIZIČKE I SPORTSKE AKTIVNOSTI NA MENTALNO ZDRAVLJE}

Svrha ovog narativnog pregleda je da se istraže dokazi o uticaju fizičkih i sportskih aktivnosti na mentalno zdravlje. Saznanja o preventivnim i tretmanskim efektima dostizanja i održavanja prosečnog nivoa fizičkih sposobnosti danas se smatraju značajnim dostignućima savremene nauke. To je uticalo na kreiranje različitih programa za unapređivanje sveukupnog zdravlja pojedinca. Akcenat je stavljen na ispitivanje psihološke dobrobiti vežbanja kako u prevenciji tako i u tretmanima stresa, depresije $i$ anksioznosti. Pozitivne $i$ negativne uticaje sportske aktivnosti na mentalno zdravlje neophodno je paralelno analizirati i primenjivati individualni pristup u načinu, pristupu, motivu, intezitetu i obimu rekreativne/sportske aktivnosti. Kada su u pitanju profesionalni sportiosti od velikog je značaja usaglašenost i fizičke i psihološke pripreme uz adekvatan stručni nadzor. Usaglašene fizičke i psihološke pripreme mogu delovati pozitivno na postignuće $i$ ostvarivanje ciljeva, ali $i$ na dobro očuvanje $i$ održavanje mentalnog zdravlja.

Ključne reči: mentalno zdravlje, fizička aktivnost, sportska aktivnost, blagostanje 